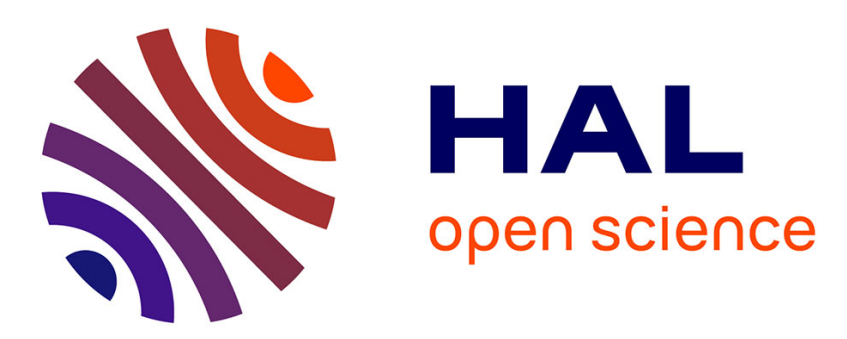

\title{
The second person in "I"-"you"-_it" triadic interactions
}

Laurent Cleret de Langavant, Charlotte Jacquemot, Anne-Catherine

Bachoud-Lévi, Emmanuel Dupoux

\section{To cite this version:}

Laurent Cleret de Langavant, Charlotte Jacquemot, Anne-Catherine Bachoud-Lévi, Emmanuel Dupoux. The second person in "I"-"you"-"it" triadic interactions. Behavioral and Brain Sciences, 2013, 36 (4), pp.416-417. 10.1017/s0140525x12001860 . hal-02326581

\section{HAL Id: hal-02326581 \\ https://hal.science/hal-02326581}

Submitted on 19 Jan 2021

HAL is a multi-disciplinary open access archive for the deposit and dissemination of scientific research documents, whether they are published or not. The documents may come from teaching and research institutions in France or abroad, or from public or private research centers.
L'archive ouverte pluridisciplinaire HAL, est destinée au dépôt et à la diffusion de documents scientifiques de niveau recherche, publiés ou non, émanant des établissements d'enseignement et de recherche français ou étrangers, des laboratoires publics ou privés. 


\section{Behavioral and Brain Sciences \\ The second person in 'l'-'you'-'it' triadic interactions \\ --Manuscript Draft--}

\begin{tabular}{|c|c|}
\hline \multicolumn{2}{|l|}{ Manuscript Number: } \\
\hline Short Title: & The second person in triadic interactions \\
\hline Article Type: & Commentary Article \\
\hline Corresponding Author: & $\begin{array}{l}\text { Emmanuel Dupoux } \\
\text { LSCP } \\
\text { FRANCE }\end{array}$ \\
\hline \multicolumn{2}{|l|}{$\begin{array}{l}\text { Corresponding Author Secondary } \\
\text { Information: }\end{array}$} \\
\hline Corresponding Author's Institution: & LSCP \\
\hline \multicolumn{2}{|l|}{$\begin{array}{l}\text { Corresponding Author's Secondary } \\
\text { Institution: }\end{array}$} \\
\hline \multicolumn{2}{|l|}{ First Author Secondary Information: } \\
\hline \multirow[t]{4}{*}{ Order of Authors: } & Laurent Cleret de Langavant, MD, PhD \\
\hline & Charlotte Jacquemot, PhD \\
\hline & Anne-Catherine Bachoud-Lévi, MD, PhD \\
\hline & Emmanuel Dupoux \\
\hline \multicolumn{2}{|c|}{ Order of Authors Secondary Information: } \\
\hline Abstract: & $\begin{array}{l}\text { Second person social cognition cannot be restricted to dyadic interactions between two } \\
\text { persons (the 'l' and the 'you'). Many instances of social communication are triadic, and } \\
\text { involve a third person (the 'him/her/it'), which is the object of the interaction. We } \\
\text { discuss neuropsychological and brain imaging data showing that triadic interactions } \\
\text { involve dedicated brain networks distinct from those of dyadic interactions. }\end{array}$ \\
\hline
\end{tabular}


Names of the authors of the target article: Leonhard Schilbach, Bert Timmermans, Vasudevi Reddy, Alan Costall, Gary Bente, Tobias Schlicht, Kai Vogeley

Word counts: abstract (60 words), main text (845 words), references (399 words), entire text (1430 words)

Commentary title: The second person in 'I'-'you'-'it' triadic interactions

Laurent Cleret de Langavant, Charlotte Jacquemot and Anne-Catherine Bachoud-Lévi* Institut National de la Santé et la Recherche Médicale \& Ecole Normale Supérieure, France 29, rue d'Ulm, 75005, Paris, France

$+33149813793$

laurent.cleret@gmail.com

charlotte.jacquemot@gmail.com

bachoud@gmail.com

Emmanuel Dupoux*

Ecole Normale Supérieure \& Ecole des Hautes Etudes en Sciences Sociales, France

29 rue d'Ulm, 75005, Paris, France

$+33144322616$

emmanuel.dupoux@gmail.com

http://WwW./scp.net/persons/dupoux/

*These authors equally contributed to the paper.

\section{Abstract}

Second person social cognition cannot be restricted to dyadic interactions between two persons (the 'I' and the 'you'). Many instances of social communication are triadic, and involve a third person (the 'him/her/it'), which is the object of the interaction. We discuss neuropsychological and brain imaging data showing that triadic interactions involve dedicated brain networks distinct from those of dyadic interactions. 


\section{Main Text}

Schilbach and collaborators defend the idea that social cognition research would benefit from studying "real-time social encounters in a truly interactive manner". Endorsing 'second person' neuroscience would bridge the gap between the solipsist view of first person perspective, and third person social psychology. We agree with this idea, but we point out that second person studies cannot be restricted to dyadic relationships between two persons. Indeed, communicative or collaborative interactions always involve a third component: an object, a person, an event or even the goal of the interaction itself. Therefore, many social interactions are intrinsically triadic ('I' talk to 'you' about 'him/her/it').

Dyadic interactions are present very early in human infants as can be seen in the emotional domain (emotional contagion, attachment, etc; see (Hobson \& Hobson 2012)) and in the communicative domain (turn taking, see (Kugiumutzakis 1998)). They are also present in social animals in a variety of behaviors (feeding, grooming, courting, dominance/submission displays, etc. (de Waal 2005)). Yet, they are distinct from triadic interactions (see Figure 1), which emerge in humans only at the end of the first year and are considered to play a pivotal role in the development of human social cognition (Baron-Cohen 2005, Charman 2003). Impairment or delay in the acquisition of these triadic interactions has been observed in patients with autism whose social and communicative skills are severely affected (BaronCohen 1989). In non-human primates only some limited abilities for triadic interactions are observed, for example instrumental pointing, in which the addressee is used to get an object of interest (Gómez 2005), or limited cooperation in hunting (de Waal \& Malini 2010), but not communicative pointing in which the addressee is invited to share the perceptual experience about an object (Tomasello \& Carpenter 2005), or fully fledged cooperation (Rekers et al. 2011). 
a

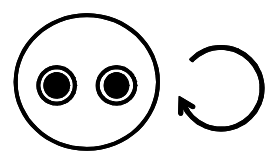

b

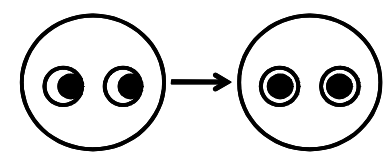

C

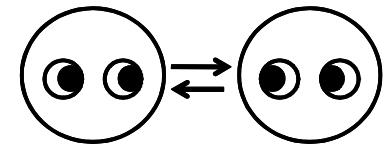

d

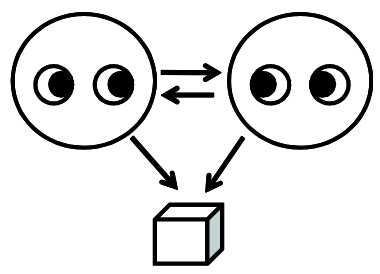

Figure 1: Four distinct perspectives in social cognition: a. first person perspective, $b$. third person perspective, c. second person perspective: dyadic interaction, d. second person perspective: triadic interaction.

Neuropsychological studies enable the disentanglement of triadic from dyadic interactions. Heterotopagnosia is a puzzling acquired deficit which only arises in triadic situations where the target object is a human person: patients cannot point at another person's body parts, although they can grasp or touch them. They can also point correctly at dolls' body parts, at videos of humans, at pieces of clothing and at their own body, thus indicating a specific difficulty for communicative pointing directed to the physical body of another human (Cleret de Langavant et al. 2009, Degos et al. 1997, Felician et al. 2003). Interestingly, most of the errors consist of pointing at their own body parts, which they rationalize by stating that the body parts of the target individual occupy the same space as their own body parts. 
Heterotopagnosia cannot be explained by a simple impairment of a human body representation or by other current theories in social cognition (Cleret de Langavant et al. 2009), but this syndrome reveals a crucial difference between dyadic and triadic interactions. Grasping and touching other's body parts involve a dyadic relationship between 'I' and the target of the gesture. In contrast pointing involves the triadic relationship of communication where 'I' show to 'you' the object 'it' or the person 'him/her'. Comparing the kinematics of pointing at objects in both communicative and non-communicative situations in healthy participants, we showed a spatial reshaping of the pointing gesture according to the communicative interaction with a second person and to his/her position relative to the first person. This suggests that in communicative pointing, we use a "heterocentric" reference frame encoding the body and perspective of the second person who is addressed ('I' represent how 'you' represent 'this'). Such a reference is not used when pointing is dyadic or in grasping or touching. PET-scan imaging shows that this reference frame involves the right posterior superior temporal sulcus region and the right medial prefrontal cortex (Cleret de Langavant et al. 2011).

In addition, because performance in heterotopagnosia differs according to the object of the pointing (a real human or a figure of human), we compared pointing at a living human's body, at a manikin's body and at artifacts in healthy participants. Reaction times for pointing at artifacts or at manikin's body parts were similar, while pointing at body parts of real persons was slower than pointing at artifacts. This demonstrated the specificity of the body of other persons: only a real person can be viewed both as a subject to communicate with ('you') or an object to communicate about ('him' or 'her'). The left posterior intra-parietal sulcus region 
was activated in healthy participants while they were pointing at another person's body (Cleret de Langavant et al. in press). Presumably, damage in this area explains why patients with heterotopagnosia cannot consider the other person under both views ('you' and 'him/her') simultaneously.

On the basis of our research on heterotopagnosia, we conclude that a 'second person' neuroscience should assess communicative/collaborative triadic interactions, as they offer a richer situation, including the switching of perspectives or frame of references between 'you' and 'him/her' perspectives. In a triadic interaction, the roles of the second and third persons are constantly dynamically redefined. This requirement should be taken into account in experimental designs using computerized avatars as opposed to real life participants.

\section{Acknowledgment}

The authors thank Laura Robotham for editing the English of this commentary.

\section{References}

Baron-Cohen, S. (1989) Perceptual role taking and protodeclarative pointing in autism. British Journal of Developmental Psychology 7: 113-127.

Baron-Cohen, S. (2005) The Empathizing System: a revision of the 1994 model of the Mindreading System. In: Origins of the Social Mind, eds. B. Ellis \& D. Bjorklund, Guilford Publications Inc.

Charman, T. (2003) Why is joint attention a pivotal skill in autism? Philosophical Transactions of the Royal Society of London B Biological Sciences 358(1430): 315324.

Cleret de Langavant, L., Remy, P., Trinkler, I., McIntyre, J., Dupoux, E., Berthoz, A. \& Bachoud-Levi, A.-C. (2011) Behavioral and neural correlates of communication via pointing. PLOS One 6(3): e17719. 
Cleret de Langavant, L., Trinkler, I., Cesaro, P. \& Bachoud-Levi, A. C. (2009) Heterotopagnosia: When I point at parts of your body. Neuropsychologia 47(7): 17451755 .

Cleret de Langavant, L., Trinkler, I., Remy, P., Thirioux, B., McIntyre, J., Berthoz, A., Dupoux, E. \& Bachoud-Levi, A. C. (in press) Viewing another person's body as a target object: a behavioural and PET study of pointing. Neuropsychologia.

de Waal, F. B. M. (2005) A century of getting to know the chimpanzee. Nature 437: 56-59.

de Waal, F. B. M. \& Malini, S. (2010) Prosocial primates: selfish and unselfish motivations. Philos Trans R Soc Lond B Biol Sci 365(1553): 2711-2722.

Degos, J.-D., Bachoud-Lévi, A.-C., Ergis, A.-M., Petrissans, J.-L. \& Cesaro, P. (1997) Selective inability to point to extrapersonal targets after left posterior parietal lesion: an objectivisation disorder? Neurocase 3: 31-39.

Felician, O., Ceccaldi, M., Didic, M., Thinus-Blanc, C. \& Poncet, M. (2003) Pointing to body parts: a double dissociation study. Neuropsychologia 41: 1307-1316.

Gómez, J. C. (2005) Joint Attention and the Notion of Subject: Insights from Apes, Normal Children, and Children with Autism. In: Joint attention: communication and other minds, eds. N. Eilan, C. Hoerl, T. McCormack \& J. Roessler, Clarendon Press.

Hobson, P. \& Hobson, J. (2012) Joint Attention or Joint Engagement? Insights from Autism. In: Joint Attention. New Developments in Psychology, Philosophy of Mind, and Social Neuroscience., ed. A. Seemann, MIT Press.

Kugiumutzakis, G. (1998) Neonatal imitation in the intersubjective companion space. In: Intersubjective communication and emotion in early ontogeny, ed. S. Braten, Cambridge University Press.

Rekers, Y., Haun, D. B. \& Tomasello, M. (2011) Children, but not chimpanzees, prefer to collaborate. Curr Biol 21(20): 1756-1758.

Tomasello, M. \& Carpenter, M. (2005) The emergence of social cognition in three young chimpanzees. Monogr Soc Res Child Dev 70(1): vii-132. 